European Journal of Business and Innovation Research

Vol.8, No.5, pp 23-37, August 2020

Published by ECRTD-UK

Print ISSN: 2053-4019(Print), Online ISSN: 2053-4027(Online)

\title{
CHALLENGES AND POTENTIALITY OF GCC COUNTRIES TOWARDS ACHIEVING SUSTAINABLE ECONOMIC GROWTH: ANALYTICAL FRAMEWORK
}

\author{
Sufian Eltayeb Mohamed ${ }^{1}$ \\ College of Law, Sultan Qaboos University, Sultanate of Oman, \\ Tel: +96895973612, E-mail sufian@squ.edu.om
}

\begin{abstract}
The paper provides an overview of the key challenges, which face GCC countries in their efforts to attain sustainable growth and development. Their capacity to diversify the economy outside the energy sector, youth unemployment and labour market imbalances represent good examples for these challenges. The paper shows the efforts made by GCC countries to diversify their economies and to have sustained growth. Achievements were not impressive in terms of innovation and human development but relative satisfactory performance is obtained in the domain of governance and infrastructure development. As a policy recommendation, the GCC countries need to adapt new diversification strategies by encouraging innovation and developing the skills of the human resources.
\end{abstract}

KEY WORDS: Oman, sustainable growth, oil, labour market imbalances, innovation JEL Classification: 010; 031; 034; O43; D72; E02; P48; Q32.

\section{INTRODUCTION}

According to Economist Intelligence Unit (EIU 2010) ${ }^{2}, \mathrm{GCC}^{3}$ countries are expected to post robust growth over the next decade in terms of both population and GDP. By 2020, the GCC population is forecast to reach $53.5 \mathrm{~m}$, a $30 \%$ increase over the level in 2000 . Over the same period, the region's real GDP is expected to grow by $56 \%$. Nominal GDP, which was US\$341.6bn in 2000, is forecast to soar to over US\$1trn in 2010 and US\$2trn in 2020 However, the increase in population and nominal GDP have two implications: first, the increase in population by a $30 \%$ in next ten years will create more pressures on the labor market and employment opportunities in the region. Second, the increase in nominal GDP and hence economic growth is mainly driven by the surge in oil revenues, which reflect a lack of diversification and dependency on oil as a single driver for economic growth.

\footnotetext{
${ }^{1}$ Assistant Professor in Economics, Head of Quality Assurance \& Academic Accreditation, College of Law - Sultan Qaboos University, P.O. Box 50, P.C. 129, Sultanate of Oman, Office phone: +968 26875327, Mobile phone: +96895973612 Alternate email: sufian@ @qu.edu.om

${ }^{2}$ Economist Intelligence Unit (EIU 2010), The GCC in 2020: Resources for Future

${ }^{3}$ GCC countries includes, Saudi Arabia, United Arab of Emirates, Qatar, Kuwait, Oman and Bahrain
} 
The dependency on oil as a single source for financing development in GGC is a big challenge as oil price is usually subject to instability and fluctuations in the international market. For example, oil prices witnessed a sharp decline, from US\$115 per barrel in June 2014 to around US\$27 per barrel in January 2016.

To address the above challenges the GCC countries should re-emphasized the importance of achieving a sustainable development path through formulating proper diversification policies and enhancing the role of the private sector and human resource development. In this paper, we will discuss the key challenges that could face GCC countries in their efforts to diversify their economies. We shall highlight the potentiality of GCC for achieving sustained growth rates and the promising areas that could help to achieve that task such as the, innovation and human development, infrastructure, and quality of institutions.

\section{Growth Records and Prospects of GCC Economies}

In the wake of high oil prices since 2003, the GCC countries have experienced strong real GDP growth. In 20100 for example, the GCC countries benefited from oil prices above US $\$ 100$ per barrel, and grew by an estimated 6.3 per cent in 2011, up from 5.6 per cent in 2010. As shown in Figure 1 below, the growth rates of GCC as computed by constant prices had increased first, up to the year 2015 and then fall to negative value in 2016 and this due to the falling prices of oil. Then start to rise as forecasted, from $2.0 \%$ in 2018 to $2.1 \%$ in 2019, before accelerating to $2.7 \%$ in 2020. (Arab Monetary Fund Reports)

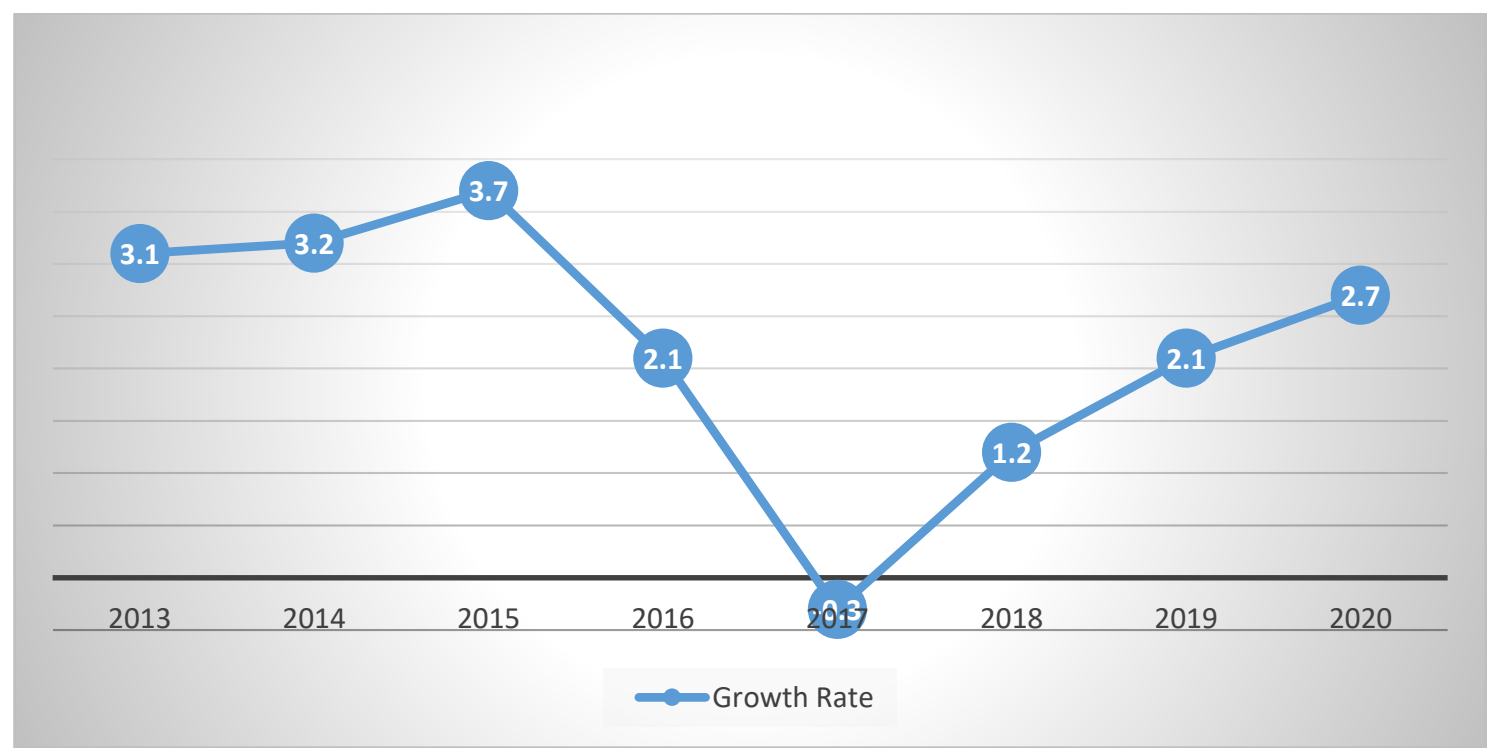

Figure 1: Real GDP Growth Rates 2018 -2020

Source: Arab Monetary Fund (Various Reports)

According to World Economic Forum Report 2019 (The Global Competitiveness Report), the GCC countries have made excellent records in the stages of development, see Table 1. 
The United Arab Emirates (UAE) for example, is ranked as a highest Arab country on the list of the 35 most advanced innovation-driven economies in the world (stage 3), which comprises some of the most developed and competitive economies in the sample, including Switzerland, the best performer in The Global Competitiveness Report 2019. The rest of GCC countries namely, Oman, Qatar, Kuwait, Saudi Arabia and Bahrain fall under transition stage. Qatar, Kuwait Saudi Arabia and Bahrain fall under transition stage. Qatar, Kuwait and Saudi Arabia ranked in the transition stage - stage 1 to stage 2. While Bahrain and Oman ranked in more advance stage - stage 2 to stage 3. This group is headed by Malaysia and Chile and comprises many emerging economies, including Brazil and the Russian Federation.

Table 1: Classification of GCC Countries into Stages of Development

\begin{tabular}{|c|c|c|}
\hline Stage of development & GCC countries & $\begin{array}{l}\text { Other countries in the } \\
\text { same stage }\end{array}$ \\
\hline \multicolumn{3}{|l|}{ Stage 1: (factor-driven) } \\
\hline Transition from stage 1 to stage 2 & $\begin{array}{l}\text { Qatar, Kuwait, Saudi } \\
\text { Arabia. }\end{array}$ & $\begin{array}{l}\text { Algeria, Libya, Venezuela, } \\
\text { Botswana }\end{array}$ \\
\hline \multicolumn{3}{|l|}{ Stage 2: Efficiency driven } \\
\hline Transition from stage 2 to stage 3 & Bahrain, Oman & Brazil, Chile, Turkey \\
\hline Stage 3: Innovation driven & United Arab Emirates & $\begin{array}{l}\text { Norway, Switzerland, } \\
\text { United States, United } \\
\text { Kingdom, Japan }\end{array}$ \\
\hline
\end{tabular}

Source: World Economic Forum, 2019

The competitiveness of most GCC countries covered by the Global Competitiveness Index (GCI) shows a robust upward trend. Record oil prices coupled with sound policies over the past few years have buoyed economic growth across GCC countries. As shown in figure (2) below, the most competitive among Gulf countries are Qatar, Saudi Arabia, and United Arab Emirates. 
Print ISSN: 2053-4019(Print), Online ISSN: 2053-4027(Online)

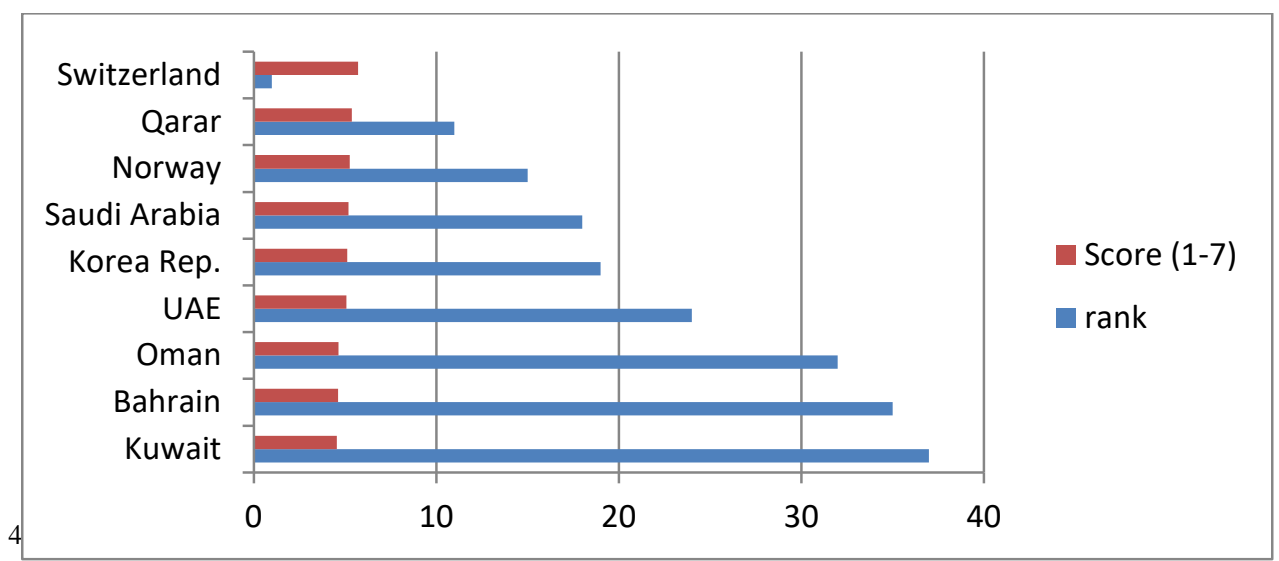

Figure 2: Global Competitiveness Index 2019

\section{Key Economic Challenges Facing GCC Countries}

The GCC economy faces three major challenges to economic development: The move away from oil and gas to non-hydrocarbon sectors and industries and achieving proper structural transformation; youth unemployment challenges and labour market imbalances..

\section{Oil Dominance Over Other Sectors}

The oil sector continues to be the greatest determinant of GDP growth for the economies of the GCC. The oil rents account for almost 80 per cent of government revenues, so the GCC economies are still heavily reliant on oil and gas to finance other sectors.

As shown from Figure 3, oil contributes high to GCC countries in terms government revenues with noticeable high in Saudi Arabia, Kuwait and Oman. This feature of dependency on oil only for generating government revenues pose common structural policy challenges to GCC economies, notably economic diversification to reduce the dependency on the hydrocarbon sector and to develop the private non-oil sector.

\footnotetext{
${ }^{4}$ Global Competitiveness Index is a measure summarizing the quality of the main aspects of a country's business climate (contracts and law, corruption, ICT infrastructure, access to credit, innovation and the efficiency of public spending). The index ranges from 1 (worst) to 7 (best)
} 
Print ISSN: 2053-4019(Print), Online ISSN: 2053-4027(Online)

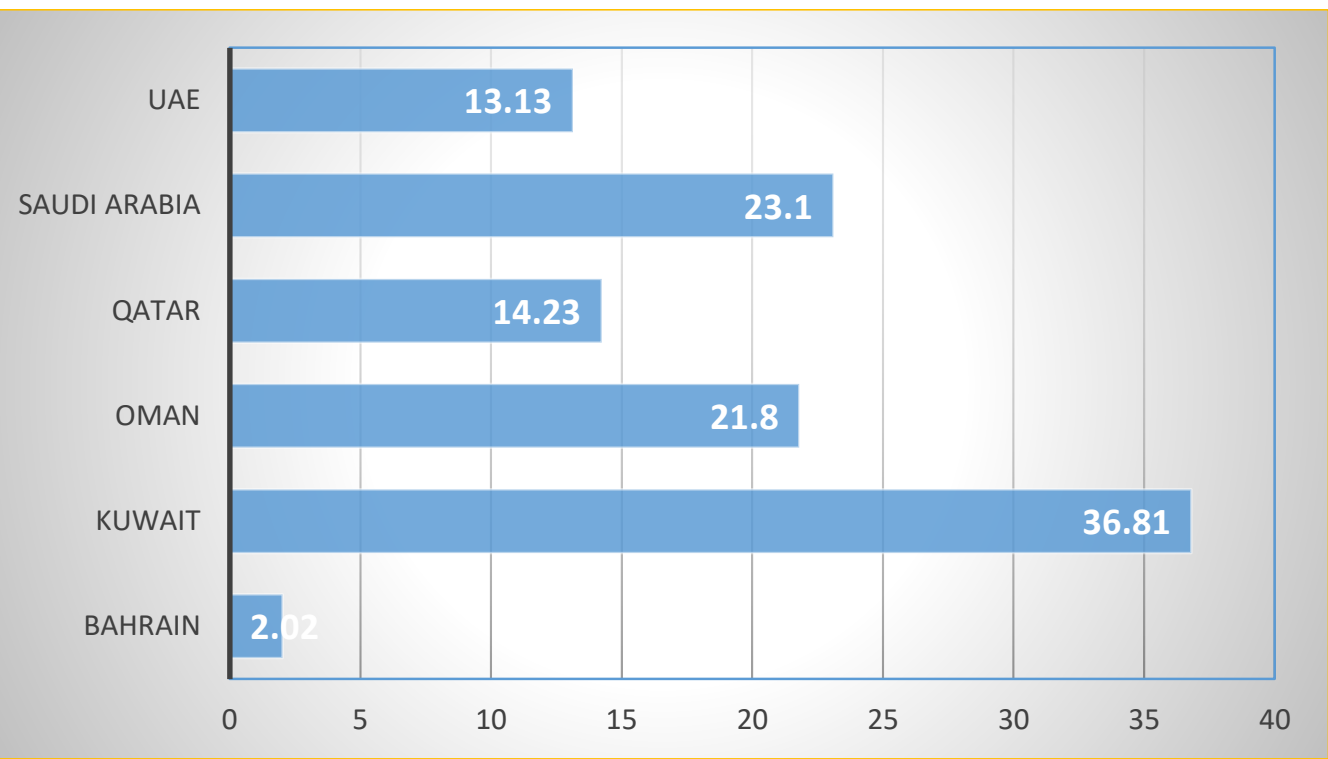

Figure 3: Revenue minus production cost of oil, percent of GDP, and 2017

Source: The World Bank, https://www.theglobaleconomy.com/rankings/Oil_revenue/Asia/

GCC economies are all heavily dependent on oil. In all of these countries, economic activity, fiscal revenue, and export earnings are directly dependent on oil production (Table 2).

Table 2: Selected Economic Indicators for GCC Countries, 2018

\begin{tabular}{|l|l|l|l|l|l|l|}
\hline Indicators & Bahrain & Kuwait & Qatar & Oman & KSA & UAE \\
\hline Nominal GDP, \$ billion & 38 & 133 & 181 & 82 & 786 & 415 \\
\hline Real GDP, \%Change & 2.0 & 1.5 & 2.1 & 2.1 & 2.2 & 1.6 \\
\hline CPI Inflation Rate. Average, \% & 2.1 & 0.6 & 2.0 & 0.9 & 2.5 & 3.1 \\
\hline Hydrocarbon Sector, \% GDP & 18.3 & 50.8 & 46.8 & 38.3 & 43.5 & 29.5 \\
\hline $\begin{array}{l}\text { Hydrocarbon Sector, \% of total } \\
\text { revenue }\end{array}$ & 75.1 & 89.3 & 82.7 & 72.9 & 67.9 & 34.5 \\
\hline $\begin{array}{l}\text { Hydrocarbon Sector, \% of total } \\
\text { export }\end{array}$ & 47.0 & 87.2 & 80.7 & 56.0 & 70.2 & 42.0 \\
\hline Crude Oil Production & 0.20 & 2.75 & 2.01 & 0.99 & 10.33 & 3.0 \\
\hline
\end{tabular}

Source: Adapted from ESCWA report based on data from balance of payment/ central banks in ESCWA region

\section{Structural Change, Productivity and Diversification}

The GCC countries' strong orientation towards oil and gas implies that the diversification of their economies is one of the key future challenges. In this concern the GCC countries made great efforts to diversify their economies away from oil and gas since these economies face a depletion of oil reserves soon (the case of Bahrain and Oman) 
European Journal of Business and Innovation Research

Vol.8, No.5, pp 23-37, August 2020

Published by ECRTD-UK

Print ISSN: 2053-4019(Print), Online ISSN: 2053-4027(Online)

${ }^{5}$.According to Hvidt, M., (2013) ${ }^{6}$, the GCC countries failed to achieve any proper transformation in their economies and hence good diversification base away from oil and gas. For example, Hvit made a summary for most of the studies, which evaluate GCC diversification efforts since 1970's, and she concluded that, to achieve diversification GCC should formulate policies to attract greater participation from the private sector. Ali $(2013)^{7}$, "also reached the same conclusion and agreed with Hvidt and the previous economists that there is "practical and theoretical difficulties for GCC countries to diversify their economies". Ali used the logic of structural transformation model to see how GCC move across time. He concluded that the $\mathrm{CC}$ failed to make a proper structural transformation and indeed these countries failed to move away from the oil dominance to promote non-oil sectors. See Table 3 below.

Table 3: Structural Reform in GCC Countries 1990-2018

\begin{tabular}{|l|l|l|l|l|l|l|l|l|}
\hline \multirow{3}{*}{ Country } & \multicolumn{2}{l|}{ Share of Sectors in GDP (\%) } \\
\cline { 2 - 10 } & \multicolumn{2}{|l|}{ Agriculture } & \multicolumn{2}{l|}{ Indusrty } & \multicolumn{2}{l|}{ Services } & \multicolumn{2}{l|}{ Manufacturing } \\
\cline { 2 - 10 } & 1990 & 2018 & 1990 & 2018 & 1990 & 2018 & 1990 & 2018 \\
\hline UAE & 1.0 & 0.74 & 58.90 & 46.79 & 40.04 & 52.47 & 7.49 & 8.92 \\
\hline Bahrain & 0.8 & 0.29 & 45.73 & 43.44 & 55.8 & 55.58 & 16.72 & 17.65 \\
\hline Saudi Arabia & 5.7 & 2.22 & 49.16 & 49.54 & 45.49 & 48.37 & 8.54 & 12.81 \\
\hline Oman & 2.7 & 2.21 & 54.10 & 46.75 & 36.7 & 47.04 & 10.5 & 38.20 \\
\hline Qatar & 0.8 & 0.18 & 55.7 & 61.06 & 32.9 & 42.57 & 5.1 & 9.20 \\
\hline Kuwait & 0.9 & 0.44 & 51.7 & 59.59 & 42.4 & 50.94 & 9.3 & 6.84 \\
\hline \multicolumn{7}{|c|}{ Source: } & he & \multicolumn{7}{c|}{ World } & & Bank,
\end{tabular}

https://www.theglobaleconomy.com/rankings/Oil_revenue/Asia/

\section{Youth Unemployment Challenges}

High growth rate of population has become a dominant challenge for GCC countries ${ }^{8}$, as it has been accompanied by rising unemployment, especially among the young. The GCC area has been characterized by one of the world's highest rates of population growth $(3.2 \%$ per year over the past decade), resulting in a very young population. The GCC's six member-nations make up one of the most youthful regions in today's world; one-third to one-half of the population is under the age of 25 . People under 25 account for 51.5 percent

\footnotetext{
${ }^{5}$ Michael Sturm, at, al (2008), GCC Countries, Economic structures, Recent Developments and Role in the Global Economy, Occasional Paper Series No.92, European Central Bank.

${ }^{6}$ Hvidt, M., (2013), "Economic Diversification in GCC Countries: Past Record and Future Trends"; research paper no. 27, www.lse.ac.uk/LSEKP.

7 Ali (2013), In the context of sustainable development: Why Gulf oil states seeking to diversify their economies? Paper presented to the Omani Economic Association six conference on Sustainability Development and Equity between Planning and Reality which will held -Saturday and Sunday 16-17 February 2013 at Muscat

8 The population of the Gulf Cooperation Council o has increased from 10 million in 1975 to 40 million in 2010 and is expected to grow rapidly to reach 53 million by 2020 .
} 
of the population in Oman, 50.8 percent in Saudi Arabia, 43.9 percent in Bahrain, 37.7 percent in Kuwait, 33.8 percent in Qatar, and 31 percent in the United Arab Emirates ${ }^{9}$.

Figure 4, below, show that Saudi Arabia has the highest youth unemployment, hovering around 29\% in 2019 followed by Kuwait and Oman with youth rates of unemployment of $15.8 \%$ and $13.19 \%$ respectively, while Kuwait's youth unemployment steadily increased from $5.83 \%$ in 2000 to $15.8 \%$ in 2019. Similarly, UAE youth unemployment rose from $5.98 \%$ in 2000 to $7.54 \%$ in 2019. Arguably, Qatar has the lowest youth unemployment rates among $\mathrm{GCC}$ countries.

Figure 4: Youth unemployment, ages 15-24 in GCC Countries 2000, 2019

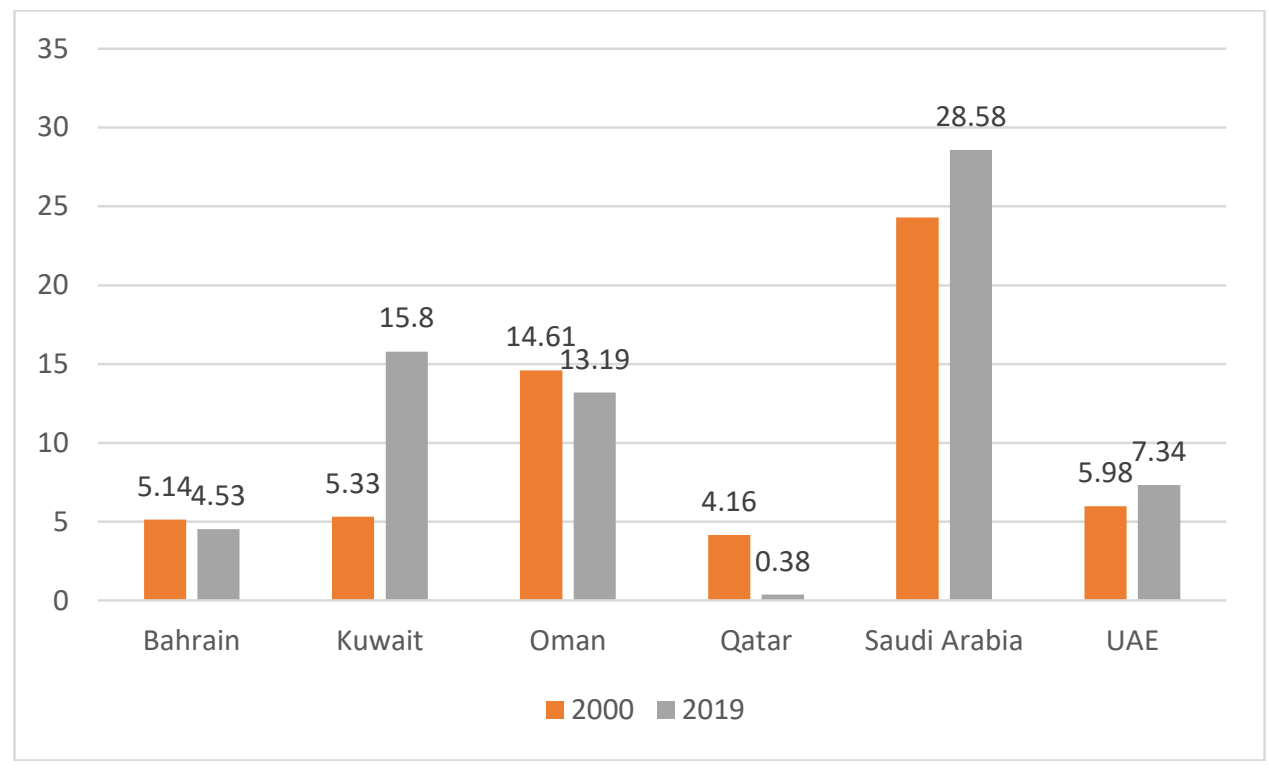

\section{Labour Market imbalances}

The member states of the Gulf Cooperation Council (GCC) represent distinctive labor markets, characterized by segmentation along several lines. These include obstinate divisions between national-non-national; public sector-private sector; male-female; bluecollar-white-collar; generation $\mathrm{X}$-generation $\mathrm{Y}$; as well as along tribal and even (increasingly) sectarian lines (Ox GAPS, 2015) ${ }^{10}$

According to IMF staff report, 2013, the public sector represent the preferred option for employment for GCC nationals. This stems largely from the nature of public sector employment, which is less demanding (in terms of working hours and accountability), safer, and better paying than the private sector, especially in the early years. The private

\footnotetext{
${ }^{9}$ The Economist, Economist Intelligence Unit, 2011

${ }^{10}$ Ox GAPS (Oxford Gulf \& Arabian Peninsula Studies Forum ) is a University of Oxford platform based at St Antony's College promoting interdisciplinary research and dialogue on the pressing issues facing the region.
} 
sector largely employs foreign labor ${ }^{11}$ where wages for foreign labor are significantly lower than those for nationals at similar education levels ${ }^{12}$.

Figure 5 below, show the interesting difference in the foreign share of workers in the public and private sectors. In Saudi Arabia, for example, about 95 percent of employment is in the public sector; in Oman, more than 80; and in UAE, about 60 percent and in Qatar about 40 percent. In contrast, public sector employment as a percentage of total employment is about 18 percent in the OECD; 15 percent in U.S.A; 16 percent in the UK; 11 percent in Germany; and 12 percent in Turkey. Public sector wages in GCC are also relatively generous, making private sector employment unattractive for nationals.

Figure 5: GCC Countries’ Labour Market, 2013

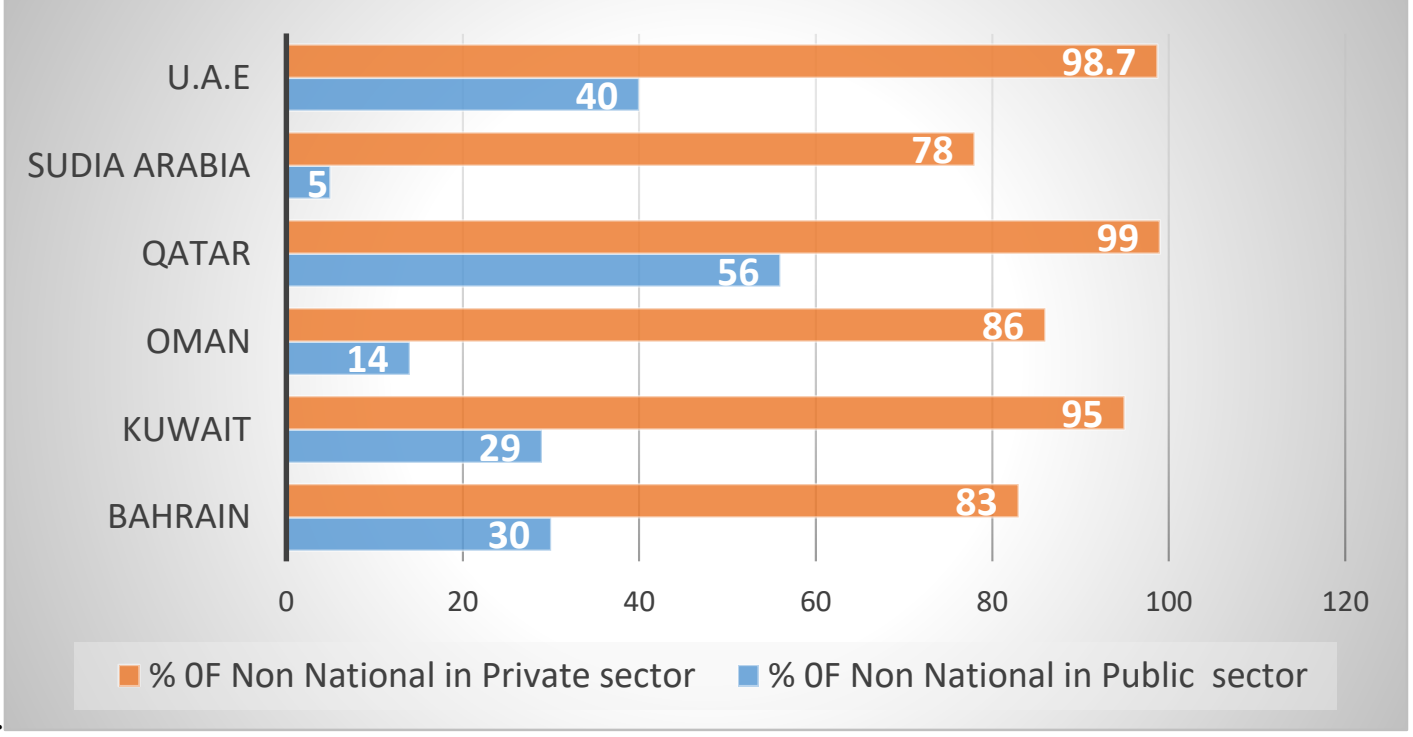

Source: GLMM, Labour force data for 2013

\section{Channels for Sustainable Growth}

The GCC countries can follow the development path to achieve sustainable growth and development. The concern to have a good quality of education is the first step towards achieving those goals. Good quality of education coupled with proper utilization of natural resources, good quality of infrastructure, and innovation will definitely enhances a nation's quality of life and standard of living. see chart 1).

\footnotetext{
${ }^{11}$ In all GCC countries, foreign labor takes up over 80 percent of private-sector jobs. 3 A majority of foreign workers in the GCC are sourced from Bangladesh, India, Nepal, Pakistan, the Philippines, and Sri Lanka.

12 Labor Market Reforms to Boost Employment and Productivity in the GCC, Prepared by Staff of the International Monetary Fund, Annual Meeting of Ministers of Finance and Central Bank Governors October 5, 2013 Riyadh, Saudi Arabia
} 
Chart 1: The Road to Sustainable Growth
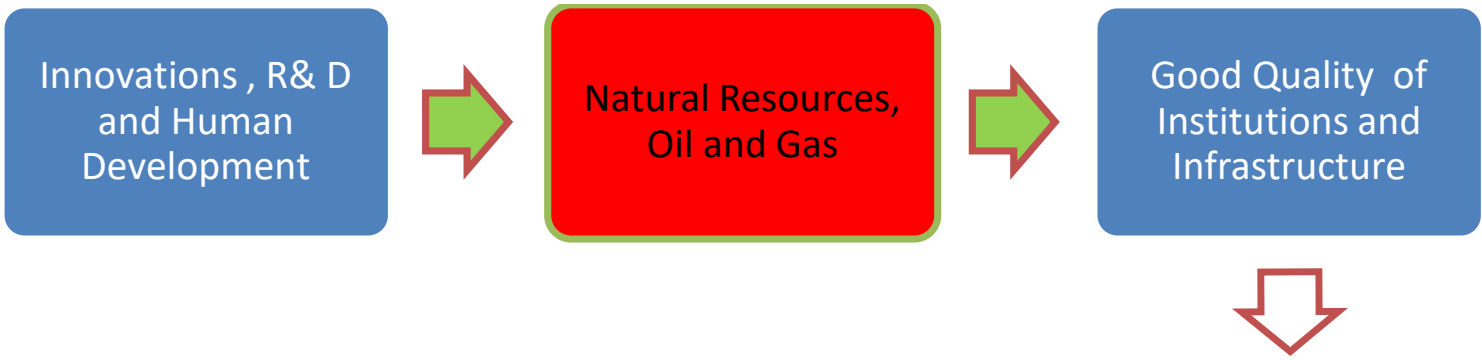

Good quality of life

and high stanadard of living

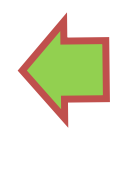

\section{High Growth rates \\ and good \\ employment \\ opportunities}

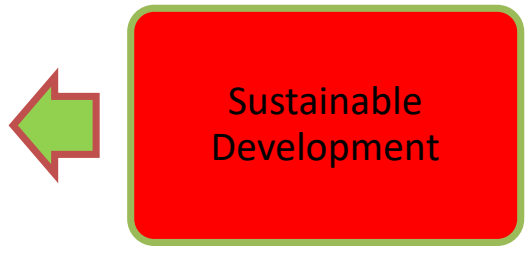

\section{Innovation and Human Development}

The GCC countries exerts great concern and effort to promote higher education as education was seen as an inevitable channel for fostering innovation in developing knowledge-based economies. The GCC countries started since late 1980s to spread the culture of innovation and they established specialized centers and parks for innovation ${ }^{13}$. Table 4 reveal some indicators, which reflect the efforts and performance of GCC counties in the area of innovation, knowledge economy, property rights and globalization. Indeed each country in the GCC region has its own economic characteristics, so their economics performance is expected to be different also. For example, for the Global Innovation Index, the table shows a large gap between GCC countries performance. This is observed in the gap between U.A.E and Oman. This gap exists because the Global Innovation Index consists of seven major indicators (Institutions, Human capital and research, Infrastructure, Market sophistication, Business sophistication, Knowledge and technology outputs and Creative output, so differences in rankings for these indicators result in this large gap. For example, in the business sophistication indicator, the UAE was ranked 4th while Oman was ranked 124th and this large gap was due to the great interest that the UAE attaches to

\footnotetext{
${ }^{13}$ For Example, the United Arab Emirates, they established Dubai International Academic City (DIAC) which is the world's largest Free Zone dedicated to Higher Education. Established in 2007 as part of the TECOM Group, DIAC aimed to develop the region's talent pool and establish the UAE as a knowledge-based economy by 2102 (DIAC). In Qatar, the Qatar Foundation established Education City in 1997. In addition to the city, Qatar also established a Science and Technology Park (QSTP) in March 2009. QSTP is a home for technology-based companies from around the world, and an incubator of start-up enterprises. Saudi Arabia also established King Abdul-Aziz City for Science and Technology, Saudi Arabia (KACST). In 2015 in Kuwait, the Kuwait Foundation for the Advancement of Sciences (KFAS) established a program (Challenge Innovation). In Bahrain, the Bahrain Development Bank and the E-Government Authority announced the start of the first batch of Technopreneur Bahrain, a holistic development program jointly initiated by the EGovernment Authority and the Bahrain Development Bank. In Oman, they established Muscat Innovation Park.
} 
Print ISSN: 2053-4019(Print), Online ISSN: 2053-4027(Online)

the business sector and the great investment opportunities, as well as the facilities it gives to foreign businessmen (Aljawareen,2017)

Table 4: Knowledge Economy, Innovation, Property rights Globalization and HDI Index in GCC Countries

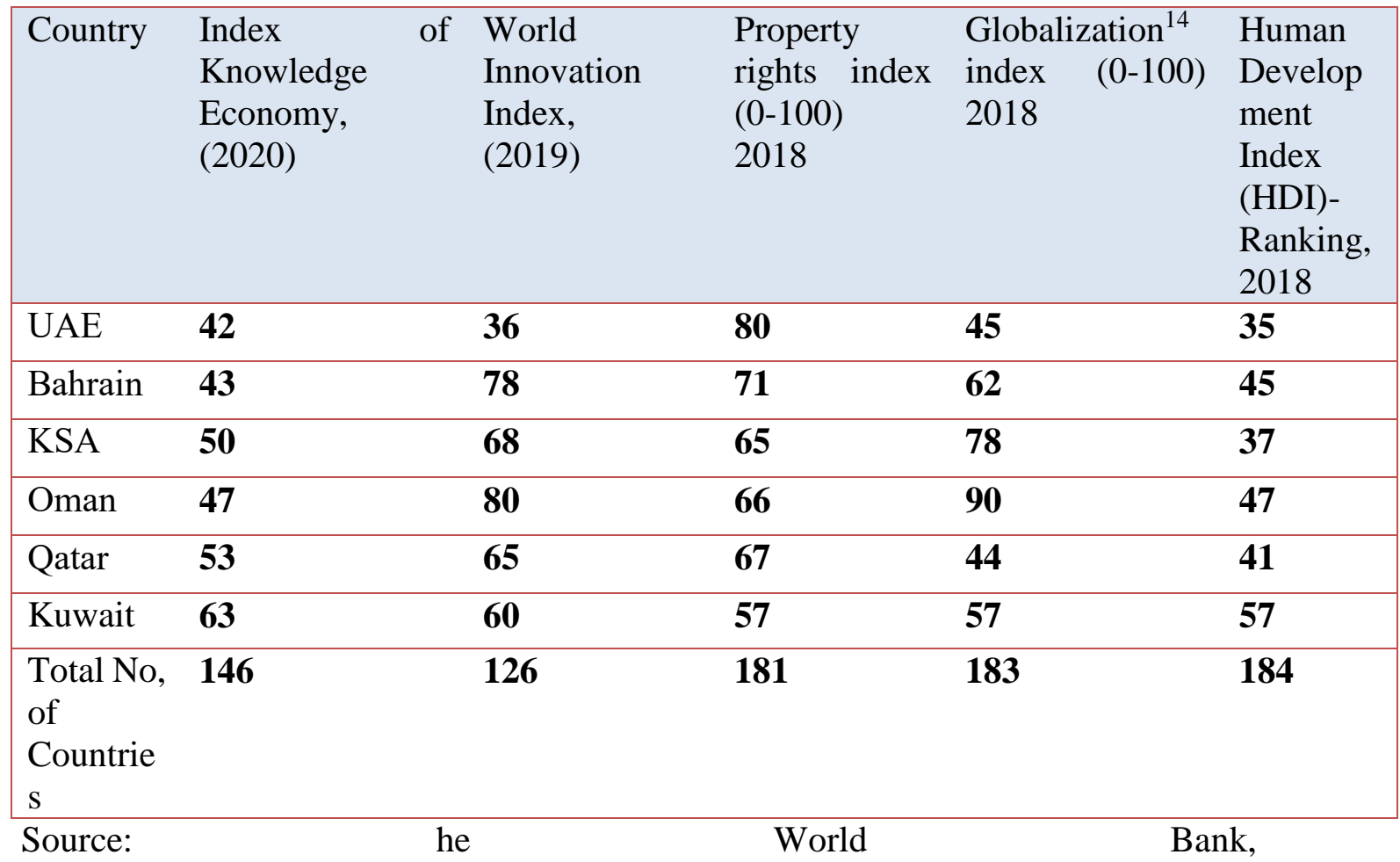

https://www.theglobaleconomy.com/rankings/Oil_revenue/Asia/

Table 5, show that there are slight increases in the number of patent applications by residents between 2016 and 2018 in some GCC countries. However, a comparison of these data with China and Japan reveals that the GCC lag behind these countries. For example, the number of patent applications in China and for the year in 2018 only. Exceeds the total number of patent applications for all GCC countries in the same year. This represent a challenge for innovation and development. In addition to thatm GCC have very low level of high technology exports as a percentage of manufactured as compared with some other Asian countries. For example the ratio in 2018 was (7.63) in Kuwait, (1.12) in Oman and (0.73) in KSA, where it was (60.17) in Philippines and (53.15), Singapore (53.15) for the same.

\footnotetext{
${ }^{14}$ Source: The Swiss Institute of Technology in Zurich
} 
Print ISSN: 2053-4019(Print), Online ISSN: 2053-4027(Online)

Table 5: Patent applications by residents in GCC (2016-2018)

\begin{tabular}{|l|l|l|l|l|}
\hline Country & $\mathbf{2 0 1 6}$ & $\mathbf{2 0 1 7}$ & $\mathbf{2 0 1 8}$ & Total \\
\hline China & $1,204.981$ & $1,245,709$ & $1,393,630$ & $2,640,543.98$ \\
\hline Japan & 260,244 & 260,292 & 253,653 & $774,189.00$ \\
\hline UAE & - & 52 & 56 & 108.00 \\
\hline nBahrai & 6 & 8 & 11 & 25.00 \\
\hline KSA & 1,070 & 909 & 1,708 & $2,617.00$ \\
\hline Oman & 3 & 4 & - & 7.00 \\
\hline Qatar & 16 & 19 & - & 35.00 \\
\hline Kuwait & 13 & - & 1 & 14.00 \\
\hline $\begin{array}{l}\text { Total No, of } \\
\text { Countries }\end{array}$ & 33 & 35 & 31 & \\
\hline \multicolumn{1}{|l|}{ Sorce Wor W } & & & & \\
\hline
\end{tabular}

Source: The World Intellectual Property Organization

One obstacle to innovation in Arab countries in general and GCC in particular is spending on R \& D. Figure 6 below shows a big variations is spending on research and development as a percentage of GDP, between GCC countries and the high performing countries, South Korea, Israel and Sweden.

Figure 6: Research and development expenditure, percent of GDP, 2018

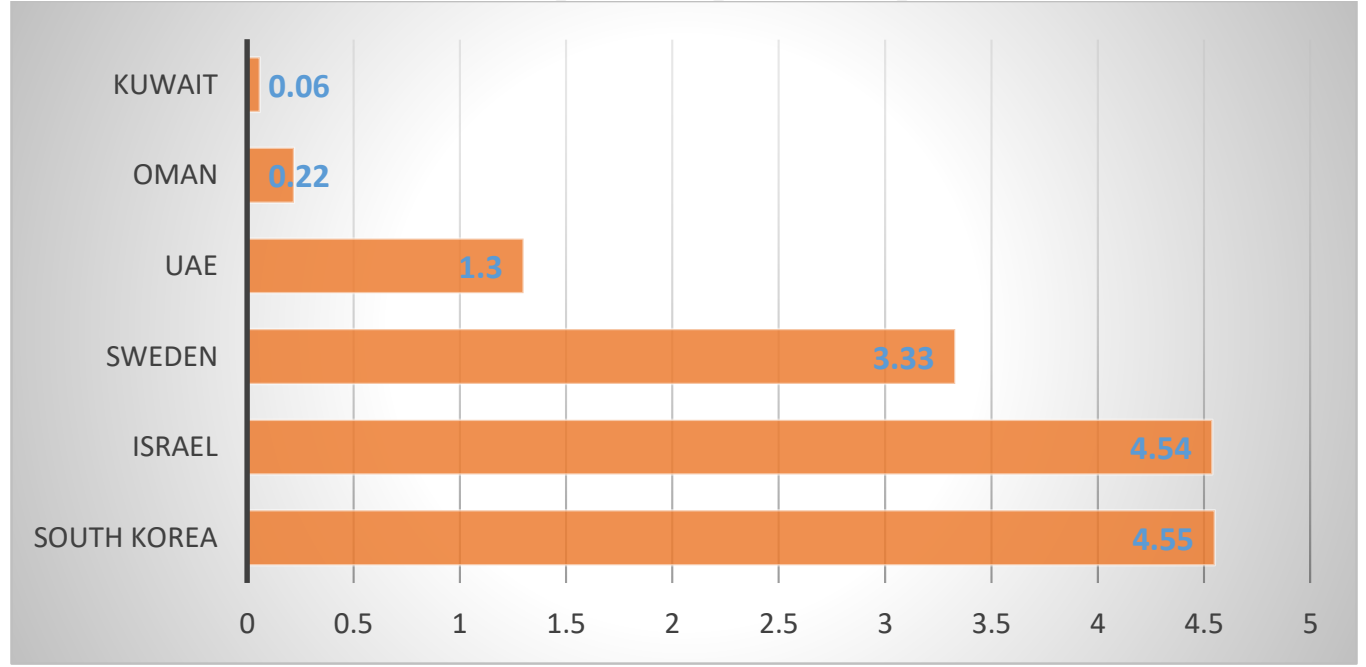

Source: The United Nations 
Print ISSN: 2053-4019(Print), Online ISSN: 2053-4027(Online)

\section{Quality of Infrastructure}

The issue of improving the quality infrastructure is a common denominator in most GCC countries development plans. Table 6 shows the efforts made by GCC for developing the infrastructure. Most of GCC rank high in term of internet users as \% of population, with Kuwait on the top. For Quality of port infrastructure ${ }^{15}$, Most of GCC countries score more than 5 out of 7 except Kuwait. For instance, the quality of port infrastructure in the UAE is amongst the highest in the world, only behind the Netherlands and Singapore, but far below OECD standards in Kuwait..

Table 6: Internet users, as \% of population and Quality of port infrastructure, 2017

\begin{tabular}{|l|l|l|l|l|}
\hline Country & $\begin{array}{l}\text { Internet } \\
\text { users as \% } \\
\text { population } \\
\text { Rank }\end{array}$ & $\begin{array}{l}\text { Index, (1- } \\
\mathbf{1 0 0})\end{array}$ & $\begin{array}{l}\text { Quality of } \\
\text { port } \\
\text { infrastructure } \\
\text { Rank }\end{array}$ & $\begin{array}{l}\text { Index, 1(low) - } \\
\text { (high) }\end{array}$ \\
\hline UAE & 16 & 94.82 & 12 & 5.50 \\
\hline Bahrain & 12 & 95.88 & 23 & 5.10 \\
\hline KSA & 38 & 82.12 & 42 & 4.80 \\
\hline Oman & 46 & 80.19 & 28 & 5.10 \\
\hline Qatar & 6 & 97.93 & 14 & 5.40 \\
\hline Kuwait & 1 & 100 & 93 & 3.5 \\
\hline $\begin{array}{l}\text { Total No, of } \\
\text { Countries }\end{array}$ & 195 & & 139 & Bank, \\
Source: & \multicolumn{4}{|c|}{ World }
\end{tabular}

https://www.theglobaleconomy.com/rankings/Oil_revenue/Asia

\section{Quality of Institutions}

Quality of institutions can be considered as one of the major factors that may hinder or facilitate economic diversification ${ }^{16}$. GCC countries achieved significant progress in building government institutions up to international standards. Good governance, fighting corruption, achieving transparency and effectiveness of government institutions are prerequisites for a successful implementation of the economic diversification strategy. International data indicate that overall, GCC countries achieved relatively satisfactory performance with respect to these indicators, but if we compare them with Norway as a

\footnotetext{
${ }^{15}$ The port quality index is a gauge of users' satisfaction with the infrastructure, obtained through a survey including several industries

${ }^{16}$ For further reading see "Dollar, D. and A. Kraay. A (2003), 'Institutions, Trade and Growth. Journal of Monetary Economics, 50, 133-162
} 
transforming economy the gab is high regarding the measure of the quality of institutions as shown in Table 7 below.

Table 7: Institutions Quality Index for GCC Countries Compared to Norway, 2018

\begin{tabular}{lllllll}
\hline Country & $\begin{array}{l}\text { Control of } \\
\text { Corruption }\end{array}$ & $\begin{array}{l}\text { Rule } \\
\text { Law }\end{array}$ & $\begin{array}{c}\text { of } \\
\text { Regulatory } \\
\text { Framework }\end{array}$ & $\begin{array}{l}\text { Government } \\
\text { Effectiveness }\end{array}$ & $\begin{array}{l}\text { Overall } \\
\text { Index }\end{array}$ \\
\hline UAE & 1.15 & 0.81 & 0.93 & 1.43 & $\mathbf{0 . 5 4}$ \\
\hline Bahrain & $-0,15$ & 0.41 & 0.45 & 0.18 & $\mathbf{0 . 5 3}$ \\
\hline KSA & 0.36 & 0.14 & 0.60 & 0.46 & $\mathbf{0 . 5 3}$ \\
\hline Oman & 0.25. & 0.46 & 0.31 & 0.19 & $\mathbf{0 . 6 2}$ \\
\hline Qatar & 0.72 & 0.73 & 0.52 & 0.53 & $\mathbf{0 . 7 2}$ \\
\hline Kuwait & -0.29 & 0.21 & -0.04 & -0.09 & $\mathbf{0 . 5 7}$ \\
\hline Norway & 0.93 & 0.99 & 0.90 & 0.85 & $\mathbf{0 . 9 2}$ \\
\hline
\end{tabular}

Source: Kauffman and Others (2018)

\section{CONCLUDING REMARKS}

In this paper, we provide an overview of the most economic challenges that face GCC countries in their effort to attain sustainable growth and development. The paper identified three major challenges that face GCC countries: the first one is the oil dominance over other sectors of the GCC economies and the capacity of the state to diversify the economy outside the energy sector. This dominance lead to the failure of all structural change programs. The second challenge is the youth unemployment and the third one is the labour market imbalances.

The paper show the effort made by GCC countries to diversify their economies and to have sustained growth. Achievements were not impressive in terms of innovation and human development as shown by their performance in these domains. Concerning governance indicators, GCC achieved relatively satisfactory performance with respect to these indicators.

As a policy recommendation, for the GCC to achieve a well-diversified and sustained growth economy, these countries would need to:

- Revise all the previous diversification policies in order to formulate a new strategy, which cope with the current challenge of innovative and technological advancement.

- $\quad$ Encourage innovation and innovates ideas

- Concentrate on raising the skill of the human resources.. 
European Journal of Business and Innovation Research

Vol.8, No.5, pp 23-37, August 2020

Published by ECRTD-UK

Print ISSN: 2053-4019(Print), Online ISSN: 2053-4027(Online)

- $\quad$ Correct the labour market imbalances by reducing the gap between the public and private sector employment

- Improve the quality of government institutions through achieving good governance, transparency and effectiveness, which are pre-requisites for a successful implementation of the economic diversification strategy.

\section{REFERENCES}

[1] Ali (2013), In the context of sustainable development: Why Gulf oil states seek to diversify their economies? Paper presented to the Omani Economic Association six conference on Sustainability Development and Equity between Planning and Reality, which took place in Muscat, Oman 16-17 February 2013

[2] Aljawareen, Adnan Farhan ( 2017), Innovation in the GCC Countries: An Economic Analysis, Journal of Economics and Development Studies December 2017, Vol. 5, No. 4, pp. 51-62, Published by American Research Institute for Policy Development DOI:10.15640/jeds.v5n4a4URL: https://doi.org/10.15640/jeds.v5n4a4.

[3] Dollar, D. and A. Kraay. A (2003), 'Institutions, Trade and Growth. Journal of Monetary Economics, 50, 133-162 73.

[4] Economist Intelligence Unit (EIU 2010), The GCC IN 2020: Resources for Future Employment and Unemployment in the GCC: GIC Monthly Economic Review, GICMER - Special Issue Sep. 2012.

[5] Esmat Zaidan, Mohammad Al-Saidi \& Suzanne H. Hammad (2019) Sustainable development in the Arab world - is the Gulf Cooperation Council (GCC) region fit for the challenge?, Development in Practice, 29:5, 670-681, DOI: 10.1080/09614524.2019.1628922 [7]Bernard, V.L., 1993. "Discussion of An Investigation of Revaluations of Tangible Long-Lived Assets". Journal of Accounting Research 31, pp. 39-45.

[6] Heston, A., R.Summers and B. Aten, (2012), Penn World Table Version: CICPIP at the University of Pennsylvania, www.sas.upenn.edu. [9] Brief, R.P., and K.V. Peasnell, 1996. "Clean surplus: A link between accounting and finance", Garland Publishing, New York.

[7] Hvidt, M., (2013), "Economic Diversification in GCC Countries: Past Record and Future Trends"; research paper no. 27, www.lse.ac.uk/LSEKP. .

[8] Kaufmann, D., Kraay, A., and M. Mastruzzi, (2010), "The Worldwide Governance Indicators: Methodology and Analytical Issues"; Policy Research Working Paper no. 5430, www.worldbank.org..

[9] Michael Sturm, at, al (2008 ), GCC Countries, Economic structures, Recent Developments and Role in the Global Economy, Occasional Paper Series No.92, European Central Bank.

[10] IMF Report (2013), Labor Market Reforms to Boost Employment and Productivity in the GCC, Prepared by Staff of the International Monetary Fund, Annual Meeting of Ministers of Finance and Central Bank Governors October 5, 2013 Riyadh, Saudi Arabia [11] Ox GAPS (2015),, the Issue 'Labor Market Dynamics in the GCC States, University of Oxford 
European Journal of Business and Innovation Research

Vol.8, No.5, pp 23-37, August 2020

Published by ECRTD-UK

Print ISSN: 2053-4019(Print), Online ISSN: 2053-4027(Online)

[12] UNCTAD, (2012), UNCTAD Handbook of Statistics 2012; www.unctad.org.

[13] World Commission on Environment and Development, (1987), Our Common Future; Oxford University Press.

[14] World Bank (2011), World Development Indicators, 2011, World Bank, Washington, 